\title{
Hypercalcaemia, Renal Dysfunction, Anaemia, Bone Disease (CRAB Criteria): A Case of Lymphoma
}

\author{
Balraj Singh ${ }^{1}$, Pooja Gogia ${ }^{2}$, Parminder Kaur ${ }^{3}$, Nirmal Guragai ${ }^{3}$, Michael Maroules $^{1}$ \\ ${ }^{1}$ Hematology \& Oncology Department, Saint Joseph's University Medical Center, Paterson, NJ, USA \\ ${ }^{2}$ Internal Medicine Department, Saint Peter's University Hospital, New Brunswick, NJ, USA \\ ${ }^{3}$ Cardiology Department, Saint Joseph's University Medical Center, Paterson, NJ, USA
}

Received: $11 / 11 / 2020$

Accepted: 29/11/2020

Published: $21 / 12 / 2020$

\begin{abstract}
How to cite this article: Singh B, Gogia P, Kaur P, Guragai N, Maroules M. Hypercalcaemia, renal dysfunction, anaemia, bone disease (CRAB criteria): a case of lymphoma. EJCRIM 2020;7: doi:10.12890/2020_002140.
\end{abstract}

Conflicts of Interests: The Authors declare that there are no competing interests.

This article is licensed under a Commons Attribution Non-Commercial 4.0 License

\section{ABSTRACT}

Calcium elevation, Renal dysfunction, Anaemia and Bone disease (CRAB criteria) are usually seen in multiple myeloma (MM). We report a unique case of lymphoma with all the features of CRAB criteria. We describe a 59-year-old patient who presented with confusion, severe back pain, fatigue and constipation and was found to have hypercalcaemia, kidney dysfunction, anaemia and multiple osteolytic lesions. Physical examination and imaging did not reveal any enlarged lymph nodes. Work-up for MM (serum protein electrophoresis, serum immunofixation, bone marrow biopsy) was negative. The patient was diagnosed with diffuse large B-cell lymphoma based on a pelvic mass biopsy. Hence, our case report suggests that CRAB criteria are not pathognomonic of MM and that in the appropriate clinical scenario, lymphoma is a possible diagnosis.

\section{LEARNING POINTS}

- The CRAB criteria consist of end-organ damage with hypercalcaemia, renal dysfunction, anaemia and bone involvement.

- The CRAB criteria are not pathognomonic of multiple myeloma, and in the appropriate clinical scenario, lymphoma is a possible diagnosis.

- Major mechanisms by which hypercalcaemia of malignancy can occur are tumour secretion of parathyroid hormone-related protein (PTHrP), osteolytic metastases with local release of cytokines, or tumour production of 1,25-dihydroxyvitamin D (calcitriol).

\section{KEYWORDS}

Hypercalcemia, anemia, osteolytic lesions, lymphoma, multiple myeloma

\section{INTRODUCTION}

Diffuse large B-cell lymphoma (DLBCL) is the most common histological subtype of non-Hodgkin lymphoma (NHL), accounting for approximately $30-40 \%$ of $\mathrm{NHL}$ cases $^{[1]}$. It is most prevalent in the elderly population and incidence increases with age. It is slightly more common in males ${ }^{[1]}$. Usual presenting signs and symptoms commonly include a rapidly growing mass; constitutional symptoms of fever, night sweats or weight loss; and/or in some patients signs and symptoms pertaining to organ involvement ${ }^{[1]}$.

The diagnosis of multiple myeloma (MM) requires clonal bone marrow plasma cells $\geq 10 \%$ or biopsy-proven bony or soft tissue plasmacytoma, and end-organ damage suggested by increased plasma calcium level, renal insufficiency, anaemia and bone lesions (CRAB) ${ }^{[2,3]}$.

Herein, we report an unusual case of DLBCL fulfilling the CRAB criteria. 


\section{CASE DESCRIPTION}

We report the case of a 59-year-old woman with a medical history of diabetes mellitus and hypertension who presented to the emergency department for confusion. According to the patient's family, she had been having difficulty in walking and had been mostly confined to bed over the previous few weeks. She had experienced unquantifiable weight loss, poor appetite, constipation and severe back pain for the past 3 months. Vital signs on presentation were stable. The patient was oriented to self only. Physical examination revealed dry oral mucosa and diminished skin turgor. The cardiovascular, respiratory, neurological and gastrointestinal examination was unremarkable. The patient did not have any palpable lymphadenopathy, macroglossia, hepatomegaly or splenomegaly. Initial blood work revealed normocytic anaemia, an elevated white count with left shift, hypovolaemic hyponatraemia, hypokalaemia, metabolic alkalosis, elevated creatinine and hypercalcaemia. Laboratory results are shown in Table 1.

The patient was started on intravenous fluids and bisphosphonates pamidronate $90 \mathrm{mg}$ IV for hypercalcaemia. A computed tomography (CT) scan of the head showed multiple lytic lesions. A skeletal survey was carried out and revealed multiple osteolytic foci in the skull, right clavicle, left humeral head, left iliac bone, left superior pubic ramus and bilateral femur. A bone scan showed increased uptake on the left femoral head and posteromedial portion of the right 10th rib (a corresponding rib fracture was noted on the CT scan). Our patient's alkaline phosphatase (ALP, a bone formation marker) was elevated at $237 \mathrm{U} / \mathrm{I}$ (reference range: 34-104 U/I), likely due to the bone healing process in the femoral head and 10th rib, and hence the increased uptake on the bone scan. The patient subsequently had serum protein electrophoresis with immune fixation studies which did not reveal any monoclonal paraproteins or light chains. However, the serum kappa lambda ratio was 3.59 (reference range: 0.2-1.65). The urine kappa lambda ratio was 49.91 (reference range 1.03-31.76), there was a urine protein electrophoresis M-spike of $6.4 \%$ (reference range: negative) and urine immunofixation was positive for kappa type Bence-Jones proteinuria.

CT scanning of the thorax, abdomen and pelvis revealed bilateral adrenal masses, liver masses, and extensive lytic osseous metastasis throughout the skeleton. Biopsy of the pelvic mass showed diffuse proliferation of large atypical lymphoid cells with a round to slightly irregular nuclear contour, and scanty to moderate amounts of cytoplasm (Fig. 1).

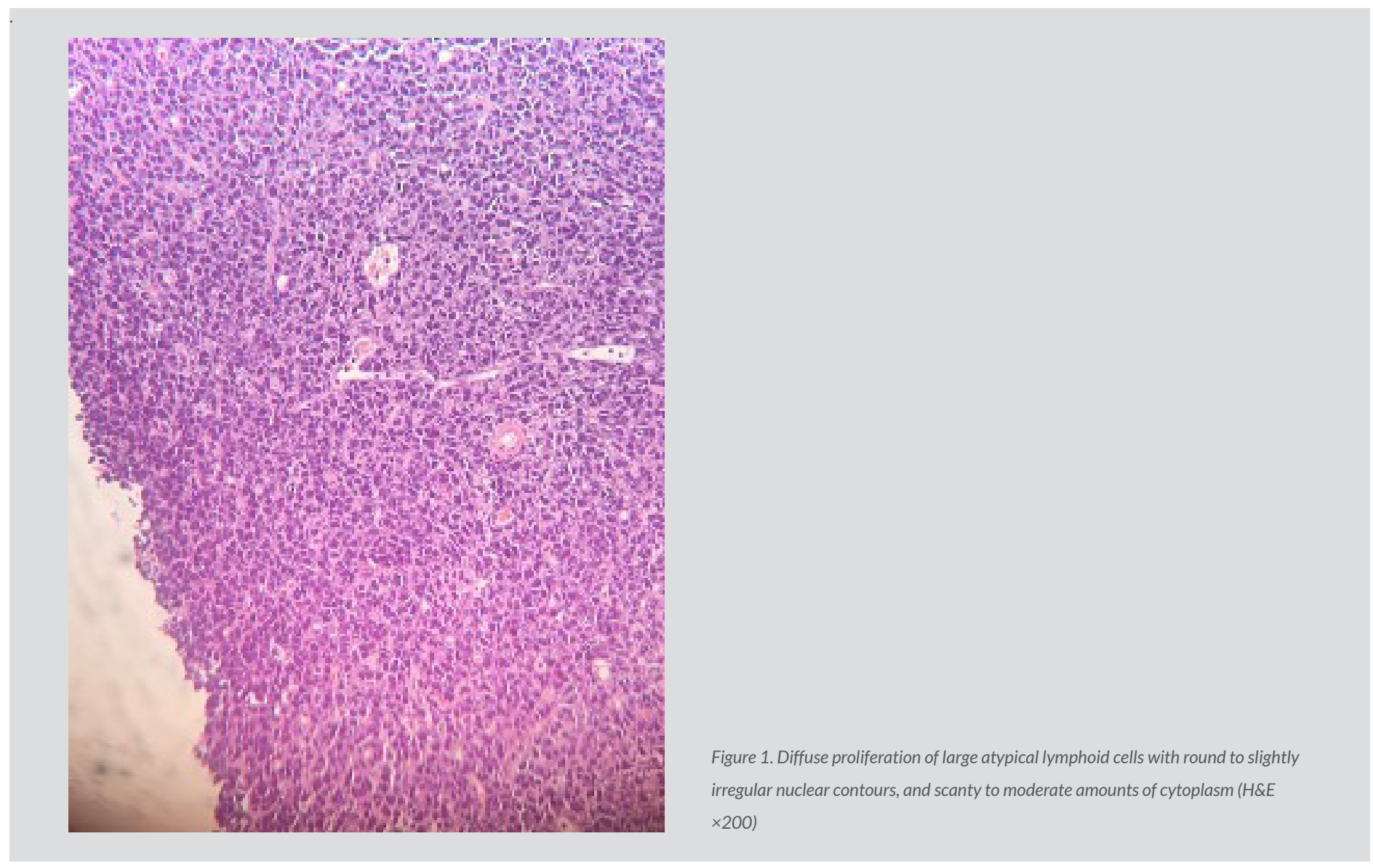




\begin{tabular}{|c|c|c|}
\hline Test & Value & Reference range \\
\hline Haemoglobin & $10.6 \mathrm{~g} / \mathrm{dl}$ & $12-16 \mathrm{~g} / \mathrm{dl}$ \\
\hline Haematocrit & $30.8 \%$ & $36-46 \%$ \\
\hline White blood cells & $23.2 \times 10^{3} / \mathrm{mm}^{3}$ & $4.5 \times 103 / \mathrm{mm}^{3}$ \\
\hline Platelets & $374 \times 10^{3} / \mathrm{mm}^{3}$ & $140-440 \times 10^{3} / \mathrm{mm}^{3}$ \\
\hline Mean corpuscular volume & $86.8 \mathrm{fl}$ & $80-100 f$ \\
\hline Red cell distribution width & $13.7 \%$ & $0.5-16.5 \%$ \\
\hline Neutrophils & $94 \%$ & $36-75 \%$ \\
\hline Lymphocytes & $1 \%$ & $24-44 \%$ \\
\hline Monocytes & $0 \%$ & $4-10 \%$ \\
\hline Eosinophil & $1 \%$ & $0-5 \%$ \\
\hline Basophil & $0 \%$ & $0-2 \%$ \\
\hline Sodium & $126 \mathrm{mEq} / \mathrm{l}$ & $135-145 \mathrm{mEq} / \mathrm{l}$ \\
\hline Potassium & $2.8 \mathrm{mEq} / \mathrm{l}$ & $3.5-5 \mathrm{mEq} / \mathrm{l}$ \\
\hline Chloride & $85 \mathrm{mEq} / \mathrm{l}$ & $98-107 \mathrm{mEq} / \mathrm{l}$ \\
\hline Bicarbonate & $30 \mathrm{mEq} / \mathrm{l}$ & $21-31 \mathrm{mEq} / \mathrm{l}$ \\
\hline Blood glucose & $143 \mathrm{mg} / \mathrm{dl}$ & $70-110 \mathrm{mg} / \mathrm{dl}$ \\
\hline Blood urea nitrogen & $57 \mathrm{mg} / \mathrm{dl}$ & $7-23 \mathrm{mg} / \mathrm{dl}$ \\
\hline Creatinine & $1.83 \mathrm{mg} / \mathrm{dl}$ & $0.6-1.30 \mathrm{mg} / \mathrm{dl}$ \\
\hline Calcium & $17.0 \mathrm{mg} / \mathrm{dl}$ & $8.6-10.3 \mathrm{mg} / \mathrm{dl}$ \\
\hline Total protein & $4.9 \mathrm{~g} / \mathrm{dl}$ & $6.4-8.4 \mathrm{~g} / \mathrm{dl}$ \\
\hline Albumin & $2.9 \mathrm{~g} / \mathrm{dl}$ & $3.5-5.0 \mathrm{~g} / \mathrm{dl}$ \\
\hline Alkaline phosphatase & $237 \mathrm{U} / \mathrm{I}$ & $34-104 \mathrm{U} / \mathrm{I}$ \\
\hline Aspartate aminotransferase & $52 \mathrm{U} / \mathrm{I}$ & $13-39 \mathrm{U} / \mathrm{I}$ \\
\hline Alanine aminotransferase & $68 \mathrm{U} / \mathrm{I}$ & $7-52 \mathrm{U} / \mathrm{I}$ \\
\hline Ferritin & $1,416 \mathrm{ng} / \mathrm{ml}$ & $12-300 \mathrm{ng} / \mathrm{ml}$ \\
\hline Lactate dehydrogenase & $527 \mathrm{U} / \mathrm{I}$ & $140-271 \mathrm{U} / \mathrm{I}$ \\
\hline Prothrombin time & 13.3 seconds & $12.2-14.9$ seconds \\
\hline International Normalized Ratio & 1 & $0.9-1.1$ \\
\hline Partial Thromboplastin time & 20 seconds & 21.3-35.1 seconds \\
\hline Parathormone (PTH) & $4.9 \mathrm{pg} / \mathrm{ml}$ & $11.1-79.5 \mathrm{pg} / \mathrm{ml}$ \\
\hline Vitamin D $25 \mathrm{OH}$ & $14.1 \mathrm{ng} / \mathrm{ml}$ & $30-100 \mathrm{ng} / \mathrm{ml}$ \\
\hline 1,25 Dihydroxy vitamin $D$ & $36.8 \mathrm{pg} / \mathrm{ml}$ & $19.9-79.3 \mathrm{pg} / \mathrm{ml}$ \\
\hline $\begin{array}{l}\text { Parathyroid hormone- } \\
\text { related protein (PTHrP) }\end{array}$ & $<2 \mathrm{pmol} / \mathrm{l}$ & $<2 \mathrm{pmol} / \mathrm{l}$ \\
\hline $\lg G$ & $357 \mathrm{mg} / \mathrm{dl}$ & $635-1471 \mathrm{mg} / \mathrm{dl}$ \\
\hline $\lg M$ & $24 \mathrm{mg} / \mathrm{dl}$ & $40-280 \mathrm{mg} / \mathrm{dl}$ \\
\hline $\lg A$ & $118 \mathrm{mg} / \mathrm{dl}$ & $66-433 \mathrm{mg} / \mathrm{dl}$ \\
\hline $\begin{array}{l}\text { Serum protein } \\
\text { electrophoresis }\end{array}$ & Negative & Negative \\
\hline Serum immune fixation & Negative & Negative \\
\hline Kappa lambda ratio & 3.59 & $0.2-1.65$ \\
\hline
\end{tabular}

Table 1. Laboratory evaluation summary 
On immunohistochemistry, the cells were diffusely strongly positive for CD20, BCL-2, BCL-6 (weak to moderate), PAX-5, MUM-1, MYC protein overexpression (80-90\%), and the Ki-67 proliferation index was $90 \%$. The large cells are negative for CD43, CD30, CD5, cyclin D1, CD138 and Pan cytokeratin. Bone marrow biopsy was negative for lymphoma involvement or a plasma cell disorder. These results supported a diagnosis of DLBCL with paraproteinaemia. Laboratory studies were negative for HIV and hepatitis B and C, and the echocardiogram was normal with an ejection fraction of $60 \%$. Lumbar puncture was negative for lymphoma involvement. The patient was started on chemotherapy with R-EPOCH (rituximab, etoposide phosphate, prednisone, vincristine sulfate, cyclophosphamide and doxorubicin hydrochloride).

\section{DISCUSSION}

The presence of the CRAB criteria, which encompass end-organ damage with hypercalcaemia, renal dysfunction, anaemia and bone involvement, is considered highly suggestive of $\mathrm{MM}^{[2]}$. However, these symptoms are neither sensitive nor specific for MM. Individual CRAB features can be present in around $74 \%$ of patients with $\mathrm{MM}^{[4]}$, and all four symptoms occur in only $30 \%$ of patients. Howsoever, there is only one case report in the literature of a patient with DLBCL presenting with CRAB features ${ }^{[3]}$.

Although our patient had a slightly elevated serum kappa lambda ratio and urine studies positive for paraproteinaemia, production of a monoclonal paraprotein has been associated with various types of B-cell non-Hodgkin lymphomas ${ }^{[5]}$. Furthermore, our patient's bone marrow biopsy was negative for a plasma cell disorder, the immunoglobulin level was not elevated, serum protein electrophoresis and immunofixation was negative, and disease burden (adrenal, liver masses, bone disease) was consistent with the diagnosis of lymphoma. Paraproteinaemia has also been associated with AL amyloidosis ${ }^{[6]}$. However, the fact that our patient did not have macroglossia, hepatomegaly, splenomegaly or an abnormal coagulation profile (factor X deficiency), that haematoxylin and eosin staining on bone marrow was negative, and the pelvic mass biopsy and echo were normal, suggested against amyloidosis.

Hypercalcaemia is reported to occur around $20 \%$ of patients with malignancy at some point during their disease and particularly in advanced stages ${ }^{[7]}$. Hypercalcemia associated with malignancy is often symptomatic and is associated with a poor prognosis [7]. The most common cancers associated with hypercalcaemia in the USA are breast, renal and lung cancer and MM. In lymphomas, hypercalcaemia is uncommon at presentation but can occur with human T-Iymphotropic virus type 1 (HTLV-1)-associated adult T-cell leukaemia-lymphoma and occasionally with transformed follicular lymphoma or $\mathrm{DLBCL}{ }^{[8]}$.

Major mechanisms by which hypercalcaemia of malignancy can occur are tumour secretion of parathyroid hormone-related protein (PTHrP), osteolytic metastases with local release of cytokines, or tumour production of 1,25-dihydroxyvitamin D (calcitriol). PTHrP or osteolytic metastases are usually the causes in solid tumours ${ }^{[9]}$. Increased production of 1,25 -dihydroxyvitamin $\mathrm{D}$ (calcitriol) is the cause of almost all cases of hypercalcaemia in Hodgkin lymphoma and approximately one-third of cases in NHL as opposed to local osteolyticinduced hypercalcaemia that is thought to be the primary mechanism in MM. PTHrP-related hypercalcaemia has also been reported in patients with $\mathrm{NHL}$ on rare occasions ${ }^{[3]}$. In our patient, the cause of hypercalcaemia was likely the extensive osteolytic metastasis with local release of cytokines; laboratory results are shown in Table 1.

Acute kidney injury (AKI) is a common occurrence in patients with cancer. In general, the same aetiologies of AKI that occur in the general population can affect cancer patients; however, certain causes of AKI are specific to the cancer patient population.

Patients with cancer are at higher risk for infections, developing sepsis, tumour lysis syndrome and treatment-associated toxicities that increase the likelihood of $\mathrm{AKI}^{[10]}$. Malignant hypercalcaemia can also cause reduced response to the antidiuretic hormone which initially presents as the inability to concentrate urine. Subsequently, the renal blood flow and glomerular filtration rate diminish due to severe calcium-induced vasoconstriction.

Anaemia is a common feature in lymphoma patients. According to the European Cancer Anaemia Survey (ECAS), 39\% of lymphoma patients were anaemic at the time they were enrolled in the survey. Anaemia has been shown to be an independent prognostic factor with a worse therapy outcome and increased mortality, and is associated with a higher stage ${ }^{[11]}$. The pathogenesis behind anaemia is likely bone marrow erythroid hypoplasia, shortened red cell survival, decreased erythropoietin production, bone marrow infiltration, hypersplenism from splenic involvement, and high inflammatory cytokine production by lymphoma cells ${ }^{[12]}$.

Bone is a frequent site of metastasis in patients with solid tumours like breast and prostate cancer and such metastasis can cause significant morbidity and mortality for patients. Haematological malignancies do not frequently cause bone disease, although $70 \%$ of patients with MM present with bone involvement at diagnosis ${ }^{[2,4]}$. Osteolytic lesions in lymphoma are found in 5-15\% of cases, and hypercalcaemia is associated with lymphoma in $10 \%$ of cases. However, it is extremely rare (approximately $2 \%$ ) for them to be the initial symptom of lymphoma ${ }^{[13]}$. Bone metastases can cause severe bone pain, pathological fractures, an oncological emergency like spinal cord compression, and derangements of calcium and phosphate homeostasis that can result in life-threatening hypercalcaemia ${ }^{[13]}$. Our patient had multiple extensive lytic lesions and fractures of the left femur head and rib. 
Our patient's alkaline phosphatase (ALP, a bone formation marker) was elevated at $237 \mathrm{U} / \mathrm{I}$ (reference range: 34-104 U/I) likely due to the healing process associated with fractures and hence the increased uptake on the bone scan. Thus, CRAB features can occur individually in DLBCL although synchronous presentation of all four features is very rare.

\section{CONCLUSION}

In conclusion, we report an unusual case of DLBCL presenting with CRAB criteria features. Our case adds to the limited literature available regarding lymphoma fulfilling CRAB criteria. Healthcare providers should have a high index of suspicion in the appropriate clinical scenario.

\section{REFERENCES}

1. Li S, Young KH, Medeiros LJ. Diffuse large B-cell lymphoma. Pathology 2018;50(1):74-87.

2. Rajkumar SV. Multiple myeloma: every year a new standard? Hematol Oncol 2019;37(Suppl 1):62-65.

3. Abdullah HMA, Ellithi M, Waqas Q, Cunningham A, Oliver T. Hypercalcaemia, renal dysfunction, anaemia and bone lesions (CRAB) do not always represent multiple myeloma: diffuse large B cell lymphoma presenting with CRAB symptoms in a 69-year-old man. BMJ Case Rep 2019;12(8):e229070.

4. Greenberg AJ, Rajkumar SV, Therneau TM, Singh PP, Dispenzieri A, Kumar SK. Relationship between initial clinical presentation and the molecular cytogenetic classification of myeloma. Leukemia 2014;28(2):398-403.

5. Dang M, Gajendra S, Goel S, Jha B, Sahni T, Sachdev R. Diffuse large B cell lymphoma with high M protein: an unusual finding. Blood Res 2015;50(1):61-62.

6. Cook L, Macdonald DHC. Management of paraproteinaemia. Postgrad Med J 2007;83(978):217-223.

7. Mirrakhimov AE. Hypercalcemia of malignancy: an update on pathogenesis and management. N Am J Med Sci 2015;7(11):483-493.

8. Conte GA, Harmon JS, Le ML, Sun X, Schuler JW, Levitt MJ, et al. Hypercalcemia in T-cell/histiocyte-rich large B-cell lymphoma: an unusual presentation of a rare disease and literature review. World J Oncol 2019;10(6):231-236.

9. Goldner W. Cancer-related hypercalcemia. J Oncol Pract 2016;12(5):426-432.

10. Rosner MH, Perazella MA. Acute kidney injury in the patient with cancer. Kidney Res Clin Pract 2019;38(3):295-308.

11. Ghosh J, Singh RK, Saxena R, Gupta R, Vivekanandan S, Sreenivas V, et al. Prevalence and aetiology of anaemia in lymphoid malignancies. NatI Med J India 2013;26(2):79-81.

12. Dicato M, Plawny L, Diederich M. Anemia in cancer. Ann Oncol 2010;21 Suppl 7:vii167-72.

13. Tsuzuki S, Park SH, Eber MR, Peters CM, Shiozawa Y. Skeletal complications in cancer patients with bone metastases. Int J Urol 2016;23(10):825-832. 